\title{
QRS Complex Absent by ECG Finding
}

National Cancer Institute

\section{Source}

National Cancer Institute. QRS Complex Absent by ECG Finding. NCI Thesaurus. Code C90441.

An electrocardiographic finding of absent QRS complexes due to a disturbance in ventricular depolarization. 